\title{
Hubungan Intensitas Belajar dengan Prestasi Belajar Siswa Jurusan Teknik Kendaraan Ringan SMK Negeri 5 Padang
}

\author{
Dodi Hermansyah $^{1^{*}}$, M Nasir ${ }^{1}$ \\ ${ }^{1}$ Jurusan Teknik Otomotif , Fakultas Teknik, Universitas Negeri Padang \\ Jln. Prof. Dr. Hamka Air Tawar Padang 25131 INDONESIA \\ *e-mail: dodihermansyah38@gmail.com \\ (Diajukan: 10 September 2020, direvisi: 1 Oktober 2020, disetujui: 31 Oktober 2020)
}

\begin{abstract}
Abstrak
Penelitian ini bertujuan untuk mengetahui adakah hubungan yang signifikan antara Intensitas Belajar Siswa Terhadap Prestasi Belajar Teknik Dasar Otomotif Kelas X Jurusan Teknik Kendaraan Ringan SMK Negeri 5 Padang. Jenis penelitian ini bersifat penelitian deskriptif korelasional. Populasi dalam penelitian ini adalah siswa kelas X Jurusan Teknik Kendaraan Ringan SMK Negeri 5 Padang sebanyak 87 orang siswa. Sedangkan teknik pengambilan sampel penelitian ini adalah simple random sampling. Sampel dalam penelitian adalah 47 orang siswa kelas X di SMK Negeri 5 Padang. Berdasarkan analisis data hasil penelitian diperoleh koefisien korelasi $\mathrm{r}$ hitung $>\mathrm{r}$ tabel $(0,995>0,361)$ dan untuk uji keberartian korelasi didapat $\mathrm{t}$ hitung $>\mathrm{t}$ tabel $(5,355>2,014)$ pada taraf signifikan $5 \%$. Maka dapat disimpulkan bahwa terdapat hubungan yang positif dan signifikan antara intensitas belajar dengan prestasi belajar siswa kelas $\mathrm{X}$ jurusan teknik kendaraan ringan SMK Negeri 5 Padang.
\end{abstract}

Kata Kunci: Intensitas Belajar, Prestasi Belajar

\begin{abstract}
This study aims to determine whether there is a significant relationship between Student Learning Intensity and Learning Achievement of Basic Automotive Engineering course for Class X, Jurusan Teknik Kendaraan Ringan, SMK Negeri 5 Padang. This is descriptive correlational research. The population in this study were 87 students. While the sampling technique of this research is simple random sampling. The sample in the study was 47 students of class $X$ at SMK Negeri 5 Padang. Based on the data analysis, the research results obtained the correlation coefficient $r$ count $>r$ table $(0.995>0.361)$ and to test the significance of the correlation obtained t count $>$ t table (5.355> 2.014) at a significant level of 5\%. So it can be concluded that there is a positive and significant relationship between learning intensity and learning achievement.
\end{abstract}

Keywords: Intensity Learning, Learning Achivements 


\section{PENDAHULUAN}

Pendidikan merupakan peranan yang sangat penting untuk menjamin kelangsungan hidup manusia dalam berbangsa dan bernegara, karena pendidikan merupakan wadah untuk meningkatkan dan mengembangkan kualitas sumber daya manusia. Pendidikan nasional berfungsi mengembangkan kemampuan dan membentuk watak serta peradaban bangsa yang bermartabat dalam rangka mencerdaskan kehidupan bangsa, bertujuan untuk mengembangkan potensi siswa agar menjadi manusia yang beriman dan bertaqwa kepada Tuhan Yang Maha Esa, berakhlak mulia, sehat, cakap, kreatif, mandiri dan menjadi warga yang demokratis dan bertanggung jawab [1]. Salah satu jenjang pendidikan untuk mencapai keberhasilan di bidang pendidikan adalah Sekolah Menengah Kejuruan (SMK). Sekolah ini merupakan lembaga pendidikan yang berfungsi untuk mempersiapkan peserta didik mengikuti pendidikan di tingkat perguruan tinggi, yang hasilnya akan dapat dilihat melalui pencapaian hasil belajar siswa yang bersangkutan. Berdasarkan hasil observasi yang dilaksanakan di SMK Negeri 5 Padang, pada mata pelajaran Teknik Dasar Otomotif Kriteria Ketuntasan Minimal (KKM) yang ditetapkan oleh SMK Negeri 5 Padang yaitu 75 dengan rentang nilai $0-100$. Bagi siswa yang nilainya $\geq 75$ dinyatakan lulus, sedangkan siswa yang nilainya $<75$ dinyatakan belum lulus dan harus mengikuti ujian remedial. Salah satu mata pelajaran produktif yang ada di SMK Negeri 5 Padang adalah Teknik Dasar Otomotif. Pada mata pelajaran Teknik Dasar Otomotif ditemukan hasil belajar siswa pada nilai semester genap kelas X Teknik Kendaraan Ringan SMK Negeri 5 Padang tahun pelajaran 2017/ 2018 masih ada yang belum mencapai KKM. Data hasil belajar siswa pada semester genap kelas X Teknik Kendaraan Ringan SMK Negeri 5 Padang dapat dilihat pada Tabel 1.

Tabel 1. Persentase Nilai Produktif Siswa Kelas X Jurusan Teknik Kendaraan Ringan Mata Pelajaran Teknik Dasar Otomotif di SMK N 5 Padang.

\begin{tabular}{|c|c|c|c|c|c|c|}
\hline \multirow{3}{*}{ No } & \multirow{3}{*}{ Kelas } & \multirow{3}{*}{ Jumlah Siswa } & \multicolumn{4}{|c|}{ Ketuntasan } \\
\hline & & & \multicolumn{2}{|c|}{ Nilai $<75$} & \multicolumn{2}{|c|}{ Niilai $\geq 75$} \\
\hline & & & Jumlah & $\%$ & Jumlah & $\%$ \\
\hline 1 & X TKR 1 & 31 & 8 & 25,81 & 23 & 74,19 \\
\hline 2 & X TKR 2 & 28 & 11 & 39,29 & 17 & 60,71 \\
\hline \multirow[t]{2}{*}{3} & X TKR 3 & 28 & 9 & 32,14 & 19 & 67,86 \\
\hline & Jumlah & 87 & 28 & 32,18 & 59 & 67,82 \\
\hline
\end{tabular}

Pada tabel terlihat bahwa dari 87 orang siswa masih ada sekitar 28 orang siswa $(32,18 \%)$ yang hasil belajarnya masih belum mencapai batas KKM. Dalam belajar siswa tidak selalu akan memperoleh keberhasilan, ada juga siswa yang memiliki kesulitan dalam belajar yang disebabkan karena beberapa faktor, intensitas belajar merupakan salah satu faktor untuk meraih prestasi belajar yang lebih baik, kurangnya intensitas belajar menyebabkan siswa mengalami masalah dalam belajarnya karena mendapatkan prestasi belajar yang rendah. Rendahnya prestasi belajar siswa dapat mengakibatkan siswa itu mengalami kegagalan dalam studinya. Akibat ketakutan akan kegagalan, dapat melemahkan usaha siswa untuk mencapai tujuan pengajaran. Berdasarkan data yang 
diperoleh, belum tercapainya hasil belajar TDO kemungkinan besar disebabkan karena kurangnya intensitas siswa dalam melaksanakan proses pembelajaran, sehingga siswa tidak mampu menerima dan mengolah materi yang diberikan. Berdasarkan latar belakang yang telah di uraikan, maka penulis ingin mengangkat judul penelitian, "Hubungan Intensitas Belajar dengan Prestasi Belajar Siswa Pada Mata Pelajaran Teknik Dasar Otomotif di Kelas X Jurusan Teknik Kendaraan Ringan SMK N 5 Padang".

\section{Belajar}

Belajar merupakan usaha seseorang untuk membangun pengetahuan dalam dirinya dan juga merupakan suatu proses dimana tingkah laku ditimbulkan atau diperbaiki melalui serentetan reaksi atas situasi (rangsangan) yang terjadi [2].

\section{Intensitas Belajar}

Intensitas belajar adalah frekuensi belajar yang dilakukan siswa selama kurun waktu tertentu untuk memperoleh pengalaman/ pengertian secara maksimal [3].

\section{Bentuk-Bentuk Intensitas Belajar}

Beberapa bentuk-bentuk dalam intensitas belajar, yaitu: a) Keteraturan belajar dan b) Kedisiplinan belajar [4].

\section{Faktor-Faktor Yang Mempengaruhi Intensitas Belajar}

Faktor-faktor yang mempengaruhi intensitas belajar, yaitu: a) Adanya keterkaitan dengan realitas kehidupan b) Harus Mempertimbangkan minat pribadi si murid c) Memberikan kepercayaan pada murid untuk giat sendiri d) Materi yang diberikan harus bersifat praktis e) Adanya peran serta dan keterlibatan siswa [5].

\section{Prestasi Belajar}

Prestasi adalah hasil dari suatu kegiatan seseorang atau kelompok yang telah dikerjakan, diciptakan dan menyenangkan hati yang diperoleh dengan jalan bekerja. Prestasi belajar merupakan bukti keberhasilan yang telah dicapai oleh seseorang. Maka prestasi belajar merupakan hasil maksimum yang dicapai oleh seseorang setelah melaksanakan usaha-usaha belajar [6]. Langkah-langkah Metode DemonstrasiDemi kelancaran metode demonstrasi, maka guru harus mengetahui langkah-langkah dalam penggunaan metode demonstrasi. Adapun Faktor-faktor yang mempengaruhi prestasi belajar yaitu faktor eksternal dan internal. Yang tergolong faktor eksternal, yaitu a) faktor sosial b) Faktor budaya c) Faktor lingkungan fisik d) Faktor lingkungan spritual. Yang tergolong faktor internal, yaitu a) Faktor jasmaniah b) Faktor psikologis c) Faktor kematangan fisik [7].

\section{Hubungan Antara Intensitas Belajar Dengan Prestasi Belajar.}

Prestasi belajar merupakan bukti keberhasilan yang telah dicapai oleh seseorang. Maka prestasi belajar merupakan hasil maksimum yang dicapai oleh seseorang setelah melaksanakan usaha-usaha belajar. Bukti keberhasilan belajar atau kemampuan seseorang siswa dalam melakukan kegiatan belajarnya adalah dengan melihat prestasi belajarnya. Faktor yang berperan penting dalam meningkatkan prestasi belajar siswa adalah intensitas belajar. Dalam memahami suatu materi pelajaran tidak mungkin dilakukan dengan satu kali baca. Dalam sekali baca pengertian maupun fakta-fakta akan segera terlupakan, karena belum tertanam dalam ingatan. Hal tersebut yang menyebabkan dalam mempelajari sesuatu materi pelajaran hendaknya berulang-ulang, 
sehingga diperoleh suatu pemahaman yang benar. Apabila siswa telah memahami materi pelajaran yang dia dapatkan maka dampaknya siswa dapat dengan mudah mengerjakan tugas maupun ujian sehingga prestasi belajarnya menjadi maksimal.

\section{Penelitian Yang Relevan}

Berdasarkan penelitian yang telah dilakukan sebelumnya maka dapat disimpulkan dari hasil penelitian menunjukan bahwa terdapat hubungan yang signifikan antara intensitas belajar dengan prestasi belajar siswa pada mata pelajaran teknik dasar otomotif di kelas x jurusan teknik kendaraan ringan SMK Negeri 5 Padang, dengan kategori interpretasi koefisien korelasi kuat. Berdasarkan temuan di atas, dapat disimpulkan bahwa intensitas belajar memberikan hubungan terhadap prestasi belajar mata pelajaran teknik dasar otomotif. Dengan demikian, intensitas belajar siswa akan sangat menentukan tingkat pencapaian tujuan belajarnya yakni meningkatkan prestasinya [8].

\section{METODE}

\section{Jenis Penelitian}

Sesuai dengan masalah yang diajukan, maka penelitian ini tergolong kepada jenis penelitian Expostfacto. Penelitian Expostfacto adalah penelitian yang dilakukan setelah fakta. Penelitian Expostfacto merupakan jenis penelitian yang mengkaji faktor-faktor yang telah terjadi yang diperkirakan dapat dijadikan sebagai penyebab dari keadaan sekarang, kemudian mencoba menyelidiki dan menganalisa faktor-faktor tersebut. Dijelaskan lebih lanjut ada beberapa jenis penelitian Expostfacto, salah satunya yaitu penelitian korelasional. Penelitian korelasional merupakan suatu penelitian yang dirancang untuk menentukan tingkat hubungan variabel-variabel yang berbeda dalam suatu populasi yang bertujuan untuk mengetahui seberapa besar pengaruh variabel (X) terhadap variabel (Y) serta bentuk hubungan yang terjadi” [9][10].

Angket dibuat, dan disebarkan setelah sebelumnya melalui standar proses instrument penelitian seperti ujicoba instrument, uji validitas dan reabilitas instrument. Lalu angket yang sudah diisi kemudian diolah dan dibahas lebih lanjut pada bagian selanjutnya.

\section{HASIL DAN PEMBAHASAN}

\section{Data Variabel Intensitas Belajar Siswa $(X)$}

Data variabel intensitas belajar siswa didapatkan melalui penyebaran kuesioner/ angket yang terdiri dari 42 butir pernyataan yang telah diuji validitas dan reliabilitasnya, selanjutnya angket diberikan kepada 47 responden untuk diisi. Data yang telah terkumpul selanjutnya diolah hingga didapatkan perhitungan statistik dasar variabel intensitas belajar siswa. Setelah penyebaran angket dilakukan maka dilakukan analisis data dan dapat disimpulkan pada grafik histogram di gambar 1.

Histogram menunjukkan kurva cendrung berdistribusi normal, hal ini memberi arti bahwa Intensitas Belajar siswa kelas X TKR di SMK N 5 Padang cenderung meningkat. Jadi dapat disimpulkan rata-rata tingkat pencapaian responden Intensitas Belajar siwa adalah sebesar $85,75 \%$ dan masuk kedalam kategori sangat tinggi. Dari data ini dapat 
dikatakan bahwa Intensitas Belajar siswa kelas X TKR di SMK N 5 Padang secara umum adalah sangat tinggi.

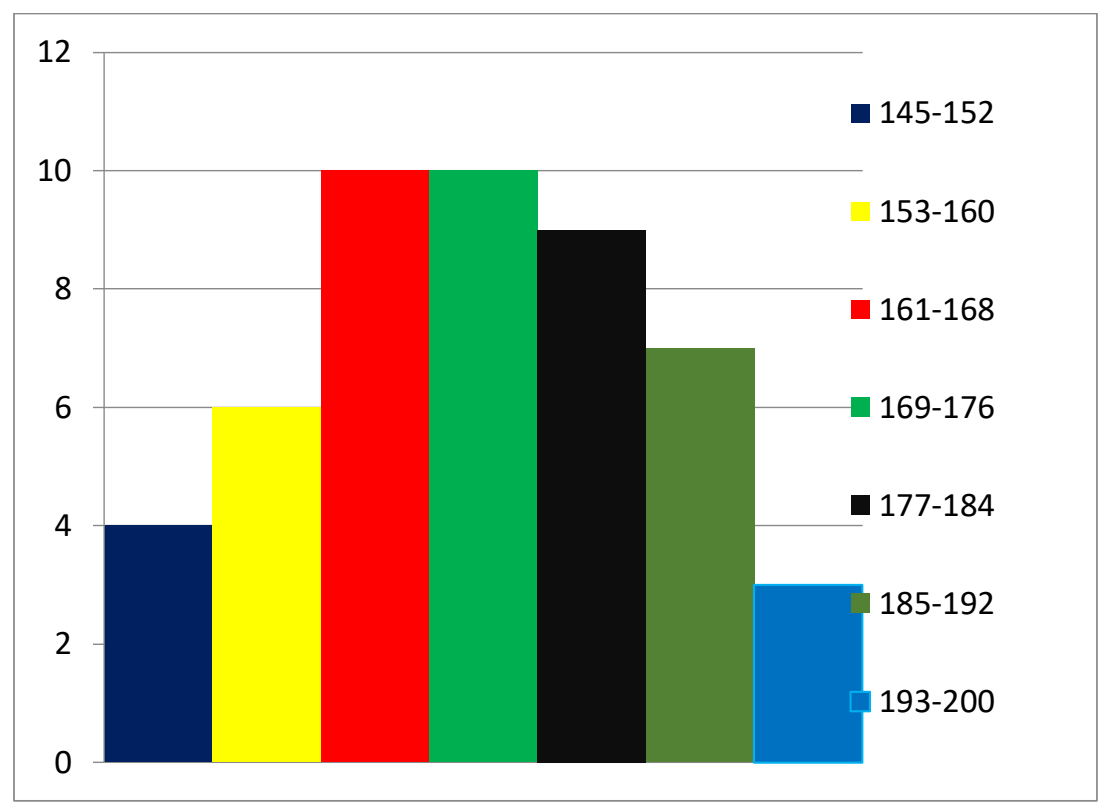

Gambar 1. Histogram Skor Intensitas Belajar Siswa (X)

\section{Data Variabel Prestasi Belajar Siswa (Y)}

Data variabel Prestasi Belajar Siswa diambil dari nilai raport sebanyak 47 Orang Siswa. Data yang telah terkumpul selanjutnya diolah hingga didapatkan perhitungan statistik dasar variabel prestasi belajar siswa. Setelah penyebaran angket dilakukan maka dilakukan analisis data dan dapat disimpulkan pada grafik histogram di gambar 2 .

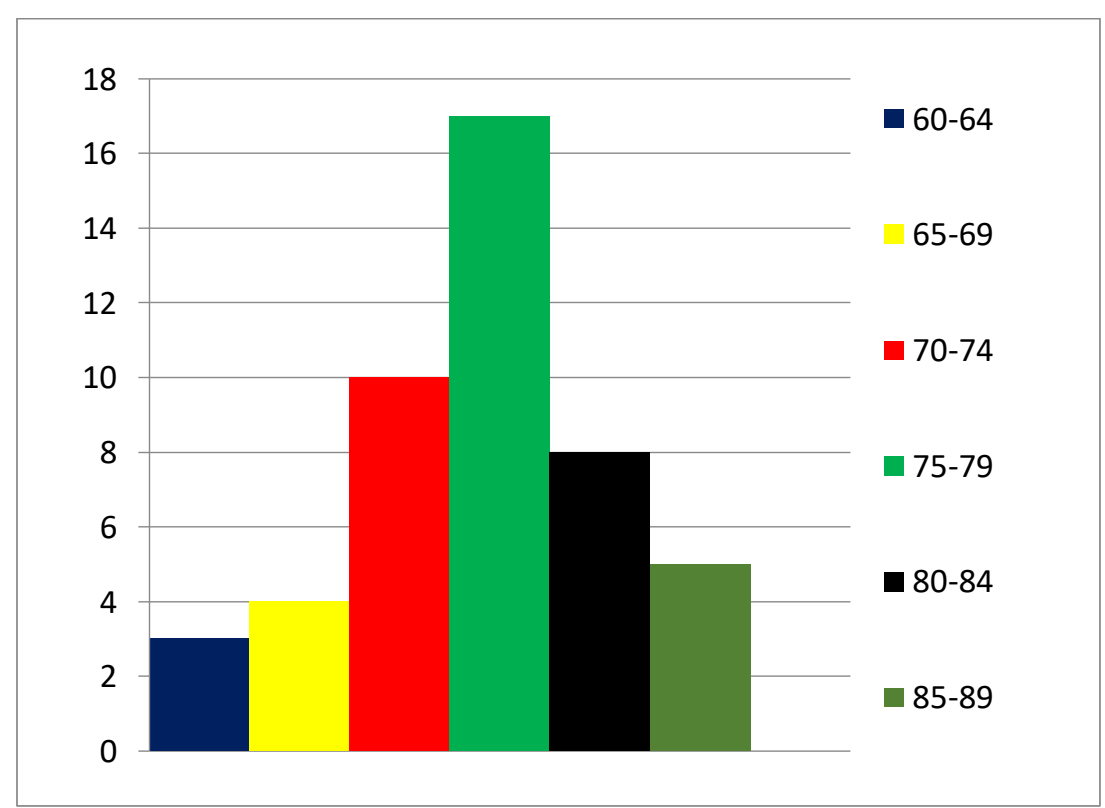

Gambar 2. Histogram Skor Prestasi Belajar Siswa (Y)

Histogram menunjukkan kurva cendrung berdistribusi normal, hal ini memberi arti bahwa Prestasi Belajar siswa kelas X TKR di SMK N 5 Padang cenderung meningkat. Jadi dapat disimpulkan rata-rata tingkat pencapaian responden Prestasi Belajar siwa 
adalah sebesar $76 \%$ dan masuk kedalam kategori tinggi. Dari data ini dapat dikatakan bahwa Prestasi Belajar siswa kelas X TKR di SMK N 5 Padang secara umum adalah tinggi.

\section{Uji Persyaratan Analisis}

\section{Uji Normalitas}

Pengujian normalitas bertujuan untuk menguji asumsi bahwa data distribusi normal. Uji normalitas dilakukan dengan menggunakan rumus chi kuadrat. Taraf signifikan yang digunakan sebagai dasar menolak atau menerima keputusan normal atau tidaknya suatu data adalah 0,05. Dikatakan normal jika $x^{2}$ hitung $<\mathrm{x}^{2}$ tabel.

Tabel 2. Uji Normalitas Data

\begin{tabular}{llrrc}
\hline No & Variabel & $x_{\text {hitung }}^{2}$ & $x_{\text {tabel }}^{2}$ & Keterangan \\
\hline 1 & Variabel (X) & $-67,559$ & 12,592 & Normal \\
2 & Variabel (Y) & $-50,010$ & 11,070 & Normal \\
\hline
\end{tabular}

Dari tabel 2 dapat dilihat nilai chi kuadrat untuk variabel (X) sebesar -67,559 dan variabel (Y) $-50,010$ dengan taraf signifikan $(\alpha)=0,05$. Berdasarkan landasan pengambil keputusan diatas maka variabel intensitas belajar siswa (X) dan varibel prestasi belajar (Y) adalah distribusi Normal.

\section{Uji Linearitas}

Uji linearitas adalah uji yang digunakan untuk melihat apakah masing-masing data variabel intensitas belajar siswa (X) membentuk distribusi linear terhadap variabel prestasi belajar teknik dasar otomotif (Y). Sebaran data variabel bebas membentuk garis linear terhadap variabel terikat dengan taraf signifikan 0,05 . Hasil uji linearitas dapat dilihat pada Tabel 3.

Tabel 3. Hasil Uji Linearitas Intensitas Belajar (X) terhadap Variabel Prestasi Belajar Siswa (Y)

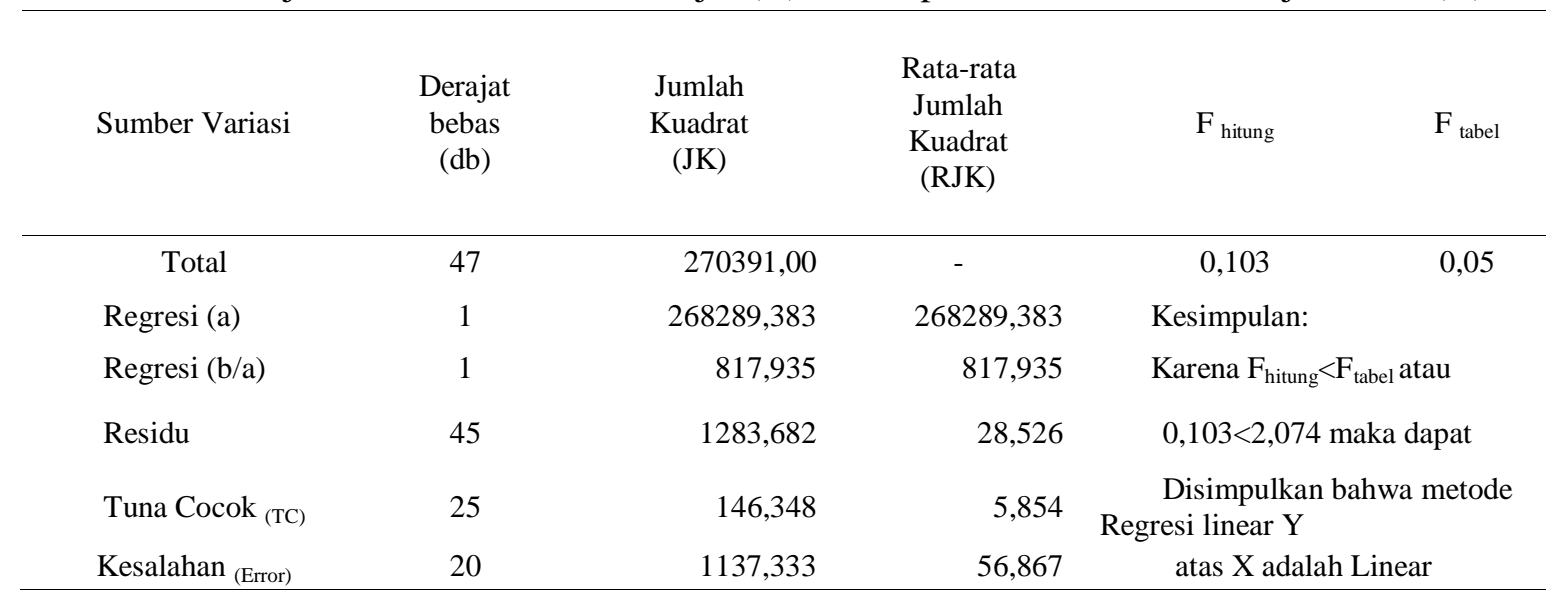

\section{Pengujian Hipotesis}

Tabel 4. Ringkasan Hasil Analisis Intensitas Belajar (X) Terhadap Prestasi Belajar Siswa (Y)

\begin{tabular}{lccc}
\hline Pengujian Hipotesis & \multicolumn{2}{c}{ Nilai } & Keterangan \\
\hline Uji Korelasi & itung $=0,624$ & bel $=0,288$ & Signifikan pada \\
$\begin{array}{l}\text { Uji Keberartian } \\
\text { Korelasi }\end{array}$ & tung $=5,355$ & bel $=2,014$ & $>0,05$ dan $\mathrm{N}=47$ \\
\hline
\end{tabular}


Dari tabel 4 dapat diketahui bahwa pengujian hipotesis angka korelasi antara Intensitas Belajar Siswa (X) terhadap Prestasi Belajar Siswa (Y) ialah sebesar $r$ hitung $=$ 0,624 dengan $\alpha=0,05$. Dengan demikian angka korelasi $r$ hitung $>r$ tabel product moment pearson $(0,624>0,288)$. Untuk mengetahui tingkat kontribusi antara variabel (X) dengan variabel (Y), hasil nilai $r$ hitung dikonsultasikan dengan Tabel Interprestasi koefisien korelasi r. Hasil dari konsultasinya ialah bahwa tingkat kontribusi antara variabel $(\mathrm{X})$ dengan variabel $(\mathrm{Y})$ tergolong kuat dengan besar nilar $\mathrm{r}$ hitung $=0,624$. Selanjutnya pada uji keberartian korelasi, didapat $\mathrm{t}$ hitung $>\mathrm{t}$ tabel $(5,355>2,014)$ dengan $\alpha=0,05$. Dengan demikian dapat disimpulkan bahwa Intensitas Belajar Siswa (X) mempunyai pengaruh yang positif dan signifikan dengan Prestasi Belajar Siswa (Y).

\section{Pembahasan}

Berdasarkan hasil analisis data dan pengujian hipotesis yang telah dilakukan maka didapat angka korelasi antara Intensitas Belajar Siswa (X) terhadap Prestasi Belajar Siswa (Y) ialah sebesar rhitung $=0,624$ dengan $\alpha=0,05$. Dengan demikian angka korelasi $\mathrm{r}$ hitung $>\mathrm{r}$ tabel product moment pearson $(0,624>0,288)$. Untuk mengetahui tingkat kontribusi antara variabel (X) dengan variabel (Y), hasil nilai $r$ hitung dikonsultasikan dengan Tabel Interprestasi koefisien korelasi r. Hasil dari konsultasinya ialah bahwa tingkat kontribusi antara variabel (X) dengan variabel (Y) tergolong kuat dengan besar nilar rhitung $=0,624$. Selanjutnya pada uji keberartian korelasi, didapat $\mathrm{t}$ hitung $>\mathrm{t}$ tabel $(5,355>2,014)$ dengan $\alpha=0,05$. Dengan demikian dapat disimpulkan bahwa Intensitas Belajar Siswa (X) terhadap Prestasi Belajar Siswa (Y) menunjukan bahwa data hasil penelitian signifikan. Dari hasil analisis dan pengujian hipotesis tersebut menunjukan bahwa data dan hasil uji dalam penelitian ini diterima secara empiris.

\section{KESIMPULAN DAN SARAN}

Terdapat hubungan yang positif dan signifikan antara intensitas belajar siswa dengan prestasi belajar siswa pada mata pelajaran teknik dasar otomotif kelas X jurusan teknik kendaraan ringan SMK Negeri 5 Padang dengan koefisien korelasi $r$ hitung $(0,624)>\mathrm{r}$ tabel $(0,288)$ dan $\mathrm{t}$ hitung $(5,355)>\mathrm{t}$ tabel $(2,014)$.

Tingkat kekuatan hubungan signifikan intensitas belajar siswa dengan prestasi belajar siswa pada mata pelajaran teknik dasar otomotif kelas $\mathrm{X}$ jurusan teknik kendaraan ringan SMK Negeri 5 Padang sebesar $(r=0,624)$. Dimana tingkat hubungan tersebut kuat. Intensitas Belajar yang baik, akan menghasilkan prestasi belajar yang tinggi/ baik pula, begitu pula sebaliknya.

Karena terdapat hubungan yang berarti antara intensitas belajar dengan prestasi belajar, maka penulis menyarankan untuk lebih meningkatkan intensitas belajar siswa sehingga prestasi belajarnya pun juga meningkat. Karena intensitas belajar bukan satu-satunya faktor yang mempengaruhi prestasi belajar, diharapkan sekolah dapat menyediakan sarana dan prasarana yang mendukung keterlaksanakan kegiatan belajar mengajar, sehingga mutu dari pendidikan lebih terjamin dan bermutu serta lulusannyapun memiliki keterampilan yang diperlukan dunia usaha sekarang ini. Penelitian selanjutnya agar lebih memperluas kajian tentang faktor-faktor yang 
mempengaruhi prestasi belajar baik dari aspek yang dikaji, jumlah responden, maupun wilayah penelitian, karena diduga masih banyak faktor-faktor yang memberikan hubungan yang signifikan terhadap prestasi belajar yang belum terungkap dalam penelitian ini.

\section{REFERENSI}

[1] Kementrian Pendidikan. (2003). Undang-Undang RI No. 20 Tahun 2003 Tentang Sistem Pendidikan Nasional. Jakarta: Kementrian Pendidikan Nasional.

[2] M. Nasir. (2012). Hubungan Motivasi Belajar Dengan Hasil Belajar Siswa Pada Standar Kompetensi Listrik Otomotif Kelas XI Kompetensi Keahlian Teknik Kendaraan Ringan SMK Negeri 2 Payakumbuh. Jurnal Penelitian Universitas Negeri Padang.

[3] Djamarah, Syaiful Bahri. (1994). Prestasi Belajar dan Kompetensi Guru. Surabaya: Usaha Nasional.

[4] Wagino. (2017). Peningkatan Prestasi dan Aktivitas Belajar Siswa Pada Pembelajaran Alat Ukur Mekanik Menggunakan Model Problem Based Learning. Jurnal Penelitian Universitas Negeri Padang.

[5] Ahmadi, H. Abu \& Widodo Supriyono. (2013). Psikologi belajar. Jakarta: Rineka Cipta.

[6] Sadirman A. M. (2004). Interaksi Dan Motivasi Belajar Mengajar. Jakarta: PT. Raja Grafindo Persada.

[7] Suharsimi Arikunto. (2010). Prosedur Penelitian Suatu Pendekatan Praktik. Jakarta: PT. Rineka Cipta.

[8] Sugiyono. (2017). Statistika untuk penelitian. Bandung: Alfabeta.

[9] Riduwan. (2008). Belajar Muda Penelitian Untuk Guru-Guru Karyawan Dan Peneliti Pemula. Bandung: Alfabet

[10]Riduwan. (2012). Belajar Mudah Penelitian Untuk Guru-Karyawan dan Peneliti Pemula. Jakarta: Alfabeta. 